\title{
Prevalence and Risk Factors Associated with Low Back Pain Among Health Care Providers in a District Hospital
}

\author{
TS Wong, MBBS, N Teo, MD, MO Kyaw, MBBS, DMed.SC, MMed SC \\ Orthopaedic Department, Sibu Hospital, Sibu, Malaysia
}

\begin{abstract}
Study design: A cross-sectional study among health care providers working at one hospital. Objective: To investigate the prevalence, the consequences and the risk factors associated with low back pain (LBP) among hospital staff. Materials and Methods: The study sample consisted of 931 health care providers who answered a pre-established questionnaire including 30 items in two languages. Results: The cumulative life-prevalence of LBP was $72.5 \%$ and the yearly prevalence was $56.9 \%$. Chronic LBP prevalence was noted $5.1 \%$ of the cases. Treatment was sought in $34.1 \%$ of LBP sufferers and $7.3 \%$ required sick leave or absence from work due to LBP. Risk factors associated with LBP were professional categories, bad body posture, lifting objects or patients and the increased levels of lifting, levels of job satisfaction and stressful job demands. Conclusion: There was a high prevalence of LBP among hospital staff, resulting in significant medical and socio-professional consequences. Many risk factors were identified that would necessitate multidisciplinary involvement to reduce the LBP incidence and related costs.
\end{abstract}

Key Words:

Low Back Pain (LBP); Hospital Members of Staff; Prevalence; Consequences; Risk Factors

\section{INTRODUCTION}

Low back pain (LBP) is a very frequently occurring phenomenon. Among adults in the general population, $70-85 \%$ were believed to experience at least one episode of low back pain at some time during their lives ${ }^{1}$. The direct and indirect costs of LBP in terms of quality of life, productivity, and employee absenteeism are enormous, making this common condition the single largest contributor to musculoskeletal disability world wide ${ }^{2}$. LBP is associated with multiple risk factors, including gender, age, lifestyle, psychosocial profile, physical demands of the workplace, social support, and pain perception ${ }^{3}$. Hospital workers seem to have higher rates of LBP compared to the general population due to physical and emotional factors involved in their occupation, such as stress ${ }^{4,6}$. These rates are not well established in Malaysia. Hence, this purpose of this study was to estimate the prevalence of LBP among hospital workers in a hospital, query as to its consequences and to identify the risk factors associated with the LBP in this population.

\section{MATERIALS AND METHODS}

Self-administered questionnaires were used in this survey. For the purposes of this study, health professionals were defined as the 8 largest groups of direct care providers in this hospital: doctors, staff nurses, community nurses, assistant medical officers, attendants, radiographers, physiotherapists and occupational therapists. Staff members in these categories were invited to complete a standardized questionnaire composed of 30 items. The investigation took place over a period of 2 months (from Jan to February 2010). For the survey, LBP was defined as a mechanical pain of the lower part of the back. LBP associated with thigh or buttock pain radiating down the lower limb was also acceptable. Chronic LBP was defined by pain lasting for more than 12 weeks. Cumulative lifetime prevalence of LBP was defined as having lower back pain at least at one time in their life. Yearly LBP prevalence represents occurrence of LBP during the last 12 months preceding the investigation. The term "LBP sufferers" included all those who had experienced LBP at any time. All the collected data have been analysed using the chi square analysis in SPSS software version 17.0 for Windows. The statistical significance level was set at 0.05 .

\section{RESULTS}

\section{Prevalence}

The response rate was $61.2 \%$ (570/931). However, only 493 $(53.1 \%)$ questionnaires were analyzed because 43 respondents were excluded from the study as they were pregnant or childbirth in the past 3 months, and 34 questionnaires were not completed. In the present study, LBP cumulative lifetime prevalence was $72.5 \%$ and the LBP prevalence in the past year was $56.9 \%$. Chronic LBP prevalence was $5.1 \%$.

\section{Demographic characteristics}

Out of the 493 respondents, $78.1 \%$ were women and $21.9 \%$ were men. Most respondents fell in the younger age groups 
with $83.2 \%$ between the age of $20-40$ years old. As for ethnicity, more than one quarter of the staffs was Iban (28.7\%), followed by Chinese (25.3\%) and Malay (23.7\%). The staff nurses' response rate was the highest (35.2\%), followed by doctors (20.9\%) and community nurses $(17.8 \%)$. Most of the respondents' working experience was of less than 5 years duration (53.5\%).

\section{Perceptions and Consequences of LBP}

More than 2/3 (84.1\%) of the LBP sufferers developed LBP only after starting work in the hospital and $84.3 \%$ of those claimed that the LBP was work related. Most respondents described their LBP as localized (64.2\%), whereas 35.8\% complained of LBP associated with numbness or pain radiating to the lower limb. The consequences of LBP on personal life and work were moderate according to most LBP sufferers $(42.5 \%$ and $45 \%$ respectively). Of LBP sufferers, $34.1 \%$ sought treatment for their symptom; of those who sought treatment, $60.5 \%$ received traditional treatments, $27.7 \%$ modern treatments and $11.8 \%$ both. Most were never diagnosed by a health care professional $(88.0 \%)$ and only 5 persons $(1.4 \%)$ underwent surgical procedures related to their LBP.

\section{Risk Factors Associated with LBP}

Factors associated with LBP were separated into demographic factors and workplace/employment factors. Demographic factors were age groups, sex, smoking and exercise, all of which showed no association to LBP in our study $(\mathrm{P}>0.005)$. The workplace/employment factors associated with LBP were the seniority in the establishment, professional categories, level of direct patient contact, work posture, necessity to lift objects or patients, previous LBP training, self reported knowledge of LBP, job satisfaction and job stress. Of these professional categories $(\mathrm{P}<0.05)$, bad body posture $(<0.001)$, lifting objects or patients, increased levels of lifting $(\mathrm{P}<0.001)$, levels of job satisfaction $(\mathrm{P}<0.001)$ and job stress $(\mathrm{P}=0.001)$ revealed significant correlation to LBP. However, seniority in the establishment $(\mathrm{P}=0.164)$, direct patient contact $(\mathrm{P}=0.061)$, levels of self reported knowledge on back care $(\mathrm{P}=0.11)$ and previous training in back care $(\mathrm{P}=0.831)$ did not appear to be correlated to LBP.

\section{DISCUSSION}

Pregnancy is closely associated with LBP with the prevalence rate ranging from $14 \% 42$ to $89.9 \% 43$. Therefore 43 respondents who had experienced pregnancy or childbirth in the past 3 months had been excluded from the results. The cumulative lifetime prevalence of LBP $(72.5 \%)$ and the LBP prevalence in the past year $(56.9 \%)$ in our survey were comparable to major LBP prevalence rates reported in the literature, which varies from $32 \%$ to $74 \%^{11,12,13,14,15}$ and $6 \%$ to $62.4 \%{ }^{16,17}$ respectively. The variability in LBP prevalence may be explained by the methodological heterogeneity used for the assessment of LBP as well as by differences in the gender, profession, and age group of the other study populations. The onset of LBP in the present study is significant $(\mathrm{P}<0.001)$ in that $84.1 \%$ of LBP sufferers developed symptoms only after starting work at the hospital. With its high prevalence, LBP among hospital staffs results in a certain degree of medical and professional consequences. The rates of treatment $(34.1 \%)$ seemed low compared to other studies ${ }^{19,20}(42.1 \%-79 \%)$, considering

Table I: Demography of the study samples

\begin{tabular}{|c|c|c|c|}
\hline & LBP sufferers $(\mathrm{N}=358)$ & No LBP $(\mathrm{N}=135)$ & P Value \\
\hline Sex & & & 0.222 \\
\hline Male & $69(19.3 \%)$ & $39(28.9 \%)$ & \\
\hline Female & $289(80.7 \%)$ & $96(71.1 \%)$ & \\
\hline Age & & & 0.051 \\
\hline $20-30$ & $169(47.2 \%)$ & $81(60.0 \%)$ & \\
\hline $31-40$ & $129(36.0 \%)$ & $32(23.7 \%)$ & \\
\hline $41-50$ & $31(8.7 \%)$ & $11(8.1 \%)$ & \\
\hline $51-60$ & $29(8.1 \%)$ & $11(8.1 \%)$ & \\
\hline Race & & & $<0.005$ \\
\hline Malay & $91(25.4 \%)$ & $26(19.3 \%)$ & \\
\hline Chinese & $71(19.8 \%)$ & $54(40.0 \%)$ & \\
\hline Indian & $6(1.7 \%)$ & $4(3.0 \%)$ & \\
\hline Iban & $116(32.4 \%)$ & $25(18.5 \%)$ & \\
\hline Others & $74(20.7 \%)$ & $26(19.2 \%)$ & \\
\hline Professions & & & $<0.005$ \\
\hline Doctor & $49(13.7 \%)$ & $54(40 \%)$ & \\
\hline Stuff nurse & 139(38.8\%) & $35(25.9 \%)$ & \\
\hline Community nurse & $68(19.0 \%)$ & $20(14.8 \%)$ & \\
\hline Assistant Medical Officer & $20(5.6 \%)$ & $8(5.9 \%)$ & \\
\hline Radiographer & $6(1.7 \%)$ & $1(0.7 \%)$ & \\
\hline Attendant & $60(16.8 \%)$ & $12(8.9 \%)$ & \\
\hline Physiotherapist & $8(2.2 \%)$ & $4(3.0 \%)$ & \\
\hline Occupational Therapist & $8(2.2 \%)$ & $1(0.7 \%)$ & \\
\hline
\end{tabular}


Table II: Perceptions and Consequences of LBP

\begin{tabular}{|c|c|}
\hline & $\begin{array}{l}\text { LBP sufferers } \\
\qquad(\mathrm{N}=358)\end{array}$ \\
\hline \multicolumn{2}{|c|}{ Develop LBP before or after working } \\
\hline Before working & $57(15.9 \%)$ \\
\hline After working & $301(84.1 \%)$ \\
\hline \multicolumn{2}{|l|}{ Related to work } \\
\hline Yes & $302(84.4 \%)$ \\
\hline No & $56(15.6 \%)$ \\
\hline \multicolumn{2}{|l|}{ Characteristic of LBP } \\
\hline Localised LBP & $230(64.2 \%)$ \\
\hline $\begin{array}{l}\text { LBP with numbness or } \\
\text { pain of the leg/buttock }\end{array}$ & $128(35.8 \%)$ \\
\hline \multicolumn{2}{|l|}{ Frequency of LBP } \\
\hline Daily & $36(10.0 \%)$ \\
\hline Weekly & $72(20.1 \%)$ \\
\hline Monthly & $154(43.0 \%)$ \\
\hline Yearly & $96(26.8 \%)$ \\
\hline \multicolumn{2}{|l|}{ Recovery of LBP } \\
\hline$<3$ weeks & $291(81.3 \%)$ \\
\hline 3-6 weeks & $32(8.9 \%)$ \\
\hline $6-12$ weeks & $10(2.8 \%)$ \\
\hline$>12$ weeks & $25(7.0 \%)$ \\
\hline \multicolumn{2}{|c|}{ Effect of LBP on personal Life } \\
\hline No Effect & $43(12.0 \%)$ \\
\hline Little Effect & $139(38.8 \%)$ \\
\hline Moderate Effect & $152(42.5 \%)$ \\
\hline Severe Effect & $24(6.7 \%)$ \\
\hline \multicolumn{2}{|l|}{ Effect of LBP on Work } \\
\hline No Effect & $46(12.8 \%)$ \\
\hline Little Effect & $122(34.1 \%)$ \\
\hline Moderate Effect & $161(45.0 \%)$ \\
\hline Severe Effect & $29(8.1 \%)$ \\
\hline \multicolumn{2}{|l|}{ Sick Leaves } \\
\hline Yes & $26(7.3 \%)$ \\
\hline No & $332(92.7 \%)$ \\
\hline \multicolumn{2}{|l|}{ Modified job due to LBP } \\
\hline Yes & $151(42.2 \%)$ \\
\hline No & $207(57.8 \%)$ \\
\hline \multicolumn{2}{|l|}{ Treatment for LBP } \\
\hline Yes & $122(34.1 \%)$ \\
\hline No & $236(65.9 \%)$ \\
\hline \multicolumn{2}{|l|}{ Types of treatment } \\
\hline Modern & $33(27.7 \%)$ \\
\hline Traditional & $72(60.5 \%)$ \\
\hline Both & $14(11.8 \%)$ \\
\hline \multicolumn{2}{|l|}{ Receive any spine surgery } \\
\hline Yes & $5(1.4 \%)$ \\
\hline No & $353(98.6 \%)$ \\
\hline \multicolumn{2}{|c|}{ Diagnosis from health care professionals } \\
\hline Yes & $43(12.0 \%)$ \\
\hline No & $315(88.0 \%)$ \\
\hline
\end{tabular}

that health care professionals would be expected to seek treatment as they have easier access to health care services. Interestingly, traditional treatments $(60.5 \%)$ were preferred over modern treatments $(27.7 \%)$ among LBP sufferers, even with their easy access to modern treatments. This is likely due to the lack of knowledge $(71.2 \%$ claimed little or no knowledge of back care) and training among the staff $(77.9 \%$ untrained). In fact, according to Gatchel et $a l^{41}$, access to health services in the acute phases of LBP episodes can have an important effect in reducing the long-term effects of LBP.

In this study, only $7.3 \%$ of LBP sufferers had ever taken sick leave due to their symptoms. This work absence rate is lower than such results in other studies, which range from $24.1 \%$ to $93 \%{ }^{18,19,20,21}$. Association between advanced age and the seniority of working experience was not a significant factor for LBP in our survey $(\mathrm{P}>0.05)$, but was reported as significant in other studies ${ }^{22-24}$. This is probably due to the younger age distribution of respondents in the present study.

Tobacco consumption was not significantly associated with LBP $(\mathrm{P}=0.139)$, a result that differs from that of Frank et al ${ }^{27}$ study where they showed that tobacco consumption was significantly associated with LBP and herniated disc conditions $^{26-28}$. This deviance may be due to the low number of smokers among the respondents in the current study $(4.5 \%)$.

Exercise or sports did not show as a protective role against LBP $(\mathrm{P}=0.332)$ in our survey. Of note, in the DemblansDechans $e{ }{ }^{30}$ study, sports activity was considered a risk factor for LBP, whereas Fanello et al. ${ }^{29}$ and Henchoz et al ${ }^{35}$ found that regular sports practice was associated with lower rate of LBP prevalence and was effective for primary and secondary prevention of LBP. Several factors can cloud these results namely, the competition level, nature of sports activity $^{30,31}$ as well as the volume and the intensity of the exercises $^{35}$.

Several professional risk factors have been identified that contribute to the prevalence of LBP in our survey. There was significant interrelationship between professional categories

Table III: Individual Risk Factors Associated With LBP

\begin{tabular}{|lrc|}
\hline Risk Factors & LBP sufferers $(\mathbf{N}=358)$ & P Value \\
\hline Smoking & $19(5.3 \%)$ & 0.139 \\
Yes & $339(94.7 \%)$ & \\
No & $116(32.4 \%)$ & 0.332 \\
Exercise & $103(28.8 \%)$ & \\
None & $139(38.8 \%)$ & \\
Few time per week & & 0.021 \\
Few times per month & $289(80.7 \%)$ & \\
Gender & $69(19.3 \%)$ & 0.051 \\
Female & $169(47.2 \%)$ & \\
Male & $129(36.0 \%)$ & \\
Age groups & $31(8.7 \%)$ & \\
20-30 & $29(8.1 \%)$ & \\
31-40 & & \\
$41-50$ & & \\
51-60 & & \\
\hline
\end{tabular}


Table IV: Professional risk factors associated with LBP

\begin{tabular}{|c|c|c|}
\hline Risk Factors & $\begin{array}{l}\text { LBP sufferers } \\
\quad(\mathrm{N}=358)\end{array}$ & P Value \\
\hline Profession category & & $<0.001$ \\
\hline Doctor & $49(13.7 \%)$ & \\
\hline Stuff nurse & $139(38.8 \%)$ & \\
\hline Community nurse & $68(19.0 \%)$ & \\
\hline Assistant Medical Officer & $20(5.6 \%)$ & \\
\hline Radiographer & $6(1.7 \%)$ & \\
\hline Attendant & $60(16.7 \%)$ & \\
\hline Physiotherapist & $8(2.2 \%)$ & \\
\hline Occupational Therapist & $8(2.2 \%)$ & \\
\hline Direct Patient Contact & & 0.061 \\
\hline Yes & $340(95.0 \%)$ & \\
\hline No & $18(5.0 \%)$ & \\
\hline $\begin{array}{l}\text { Perform Lifting patient } \\
\text { or objects }\end{array}$ & & $<0.001$ \\
\hline Yes & $334(93.3 \%)$ & \\
\hline No & $24(6.7 \%))$ & \\
\hline No of lift/Transfer & & $<0.001$ \\
\hline None & $24(6.7 \%)$ & \\
\hline $1-5$ & $209(58.4 \%)$ & \\
\hline $6-10$ & $83(23.2 \%)$ & \\
\hline $11-15$ & $19(5.3 \%)$ & \\
\hline$>15$ & $23(6.4 \%)$ & \\
\hline Bad body posture & & $<0.001$ \\
\hline Yes & $222(62.0 \%)$ & \\
\hline No & $136(38.0 \%)$ & \\
\hline Knowledge & & 0.11 \\
\hline Not Knowledgeable & $43(12.0 \%)$ & \\
\hline Little Knowledgeable & $212(59.2 \%)$ & \\
\hline Knowledgeable & $103(28.8 \%)$ & \\
\hline Training & & 0.831 \\
\hline Yes & $79(22.1 \%)$ & \\
\hline No & $279(77.9 \%)$ & \\
\hline Job Satisfaction & & $<0.001$ \\
\hline Poor & $59(16.5 \%)$ & \\
\hline Neutral & $226(63.1 \%)$ & \\
\hline High & $73(20.4 \%)$ & \\
\hline Stressful & & 0.001 \\
\hline Agree & $205(57.3 \%)$ & \\
\hline Neutral & $128(35.8 \%)$ & \\
\hline Disagree & $25(7.0 \%)$ & \\
\hline Working Experience & & 0.164 \\
\hline $0-5$ years & $182(50.8 \%)$ & \\
\hline $6-10$ years & $74(20.7 \%)$ & \\
\hline $11-15$ years & $43(12.0 \%)$ & \\
\hline $16-20$ years & $16(4.5 \%)$ & \\
\hline$>20$ years & $43(12.0 \%)$ & \\
\hline
\end{tabular}

and LBP $(\mathrm{P}<0.001)$ with staff nurses $(38.8 \%)$ and community nurses (19\%) most commonly reporting LBP. The high LBP prevalence among nurses can be explained by the high workloads and work conditions, particularly the requirement for heavy lifting. Some studies ${ }^{32,33,34}$ showed that administrative staff members were more affected by LBP than nurses due to the necessity to be in a seated position for prolonged periods of time and the sedentary nature of their activities $^{33}$. This is a limitation of this study as this group was not included in the survey. OF those respondents who were required to lift heavy loads and frequent lifts/transfers, $87.4 \%$ shown to have a higher likelihood of developing LBP $(\mathrm{P}<0.001)$. This result was in accordance with the results of Barrero et $a l^{19}$ and Smedley et al ${ }^{25}$ where both studies reported that lifting was an important exposure variable associated with LBP. Similarly, poor work posture was also significantly correlated with LBP prevalence in this survey $(\mathrm{P}<0.001)$. In the literature, prolonged standing position and leaning forward are frequently associated with $\operatorname{LBP}^{36,20,33}$.

Our survey showed that respondents who experience higher levels of stress in their work and who had poor job satisfaction demonstrated significant association with complaints of LBP $(\mathrm{P}<0.005)$. An unsettled psychological profile has previously been well documented to be associated with LBP, especially among chronic LBP sufferers ${ }^{37,38,39}$. Previous training in back care and the level of knowledge of back care showed no protective roles against LBP in the present study $(\mathrm{P}>0.005)$. According to Burton et al ${ }^{40}$, knowledge of proper ergonomics may not translate to prevention of LBP. Additionally, since this study is a cross sectional study, our finding may be reflective of those LBP sufferers who sought training in back care.

\section{CONCLUSION}

LBP has a high prevalence among hospital staff members and causes significant medical and socio-professional consequences. Individual risk factors and the professional risk factors noted in this survey were in accordance with most literature findings. The high prevalence of LBP requires multidisciplinary involvement in order to reduce the disability and cost imposed. 


\section{REFERENCES}

1. Andersson GB, Epidemiological features of chronic low-back pain, Lancet 1999: 581-5.

2. Coste J, Delecoeuillerie G, Cohen de Lara A, et al. Clinical course and prognostic factors in acute low back pain: an inception cohort study in primary care practice. BMJ 1994; 308: 577-80.

3. Schneider S, Randoll D, Buchner M. Why do women have back pain more than men? A representative prevalence study in the Federal Republic of Germany. Clin J Pain 2006; 22: 738-47.

4. Bejia I, Younes M, Jamila HB, et al. Prevalence and factors associated to low back pain among hospital staff. Joint Bone Spine 2005; 72: 254-9.

5. The prevalence of low back pain among doctors of hospital Kuala Lumpur, Normadiah J, NCD Malaysia 2005, volume 4, No. 2.

6. Landry MD, Raman SR, Sulway C, Golightly YM and Elham Hamdan. Prevalence and Risk Factors Associated With Low Back Pain Among Health Care Providers in a Kuwait Hospital. Spine, 2008; 33(5): 539-45.

7. Andersson GBJ. The epidemiology of spinal disorders. In Frymoyer JW, ed. The adult spine: principles and practice, 2nd ed. Philadelphia: Lippincott-Raven, 1997: 93-141.

8. Praemer A, Furnes S, Rice DP. Musculoskeletal conditions in the United States. Rosemont: AAOS, 1992: 1-99.

9. Taylor VM, Deyo RA, Cherkin DC, Kreuter W. Low-back pain hospitalization: recent United States trends and regional variations. Spine 1994; 19: 1207-13.

10. Hart LG, Deyo RA, Cherkin DC. Physician office visits for low back pain. Spine 1995; 20: 11-9.

11. Hoffmann F, Stossel U, Michaelis M, Nubling M and Siegel A. Low back pain and lumbago-sciatica in nurses and a reference group of clerks: results of a comparative prevalence study in Germany. Int Arch Occup Environ Health 2002; 484-90.

12. Bezzaoucha A, Epidémiologie descriptive de la lombalgie à Alger. Rev Rhum Mal Ostéo Art 1992; 121-4.

13. Cassou B and Gueguen S, Prévalence et facteurs de risque de la lombalgie une enquête épidémiologique et rétrospective parmi le personnel d'un hôpital parisien. Arch Mal Prof 1985; 23-9.

14. Charbotel B, Systchenko B, Ladreyt J T and Bergeret A, Evaluation de la fréquence des troubles musculo-squelettiques dans une blanchisserie hospitalière. Arch Mal Prof 2003; 77-82.

15. Smedley J, Egger P, Cooper C and Coggon D. Manual handling activities and risk of low back pain in nurses. Occup Environ Med 1995; 160-3.

16. Gaudemaris R D, Blatier J F, Quinton B, Piazza E, Gallin C-Martel et al., Analyse du risque lombalgique en milieu professionnel. Rev Epidémiol Santé Publ 1986; 308-17.

17. Burgmeier A C, Blindauer B and Lehmann R. Incidence, prévalence et facteurs de risque de lombalgies hospitalières. Perspective de prévention. Med Trav 1987; 28-34.

18. Bejia I, Younes M, HB Jamila, Khalfallah T, Salem K, Touzi M, M Akrout and N Bergaoui. Prevalence and factors associated to low back pain among hospital staff. Joint Bone Spine 2005; 72(3): 254-9.

19. Barrero LH, Hsu YH, Terwedow H, et al. Prevalance and physical determinants of low back pain in a rural Chinese population. Spine 2006: 31: 2728-34.

20. Caillard JF, Czernichow P and Doucet J. Le risque lombalgique professionnel à l'hôpital. Arch Mal Prof 1987; 623-9.

21. Charuel C, Romazini S, Gallin-Martel C, Martin A, Schlumberger HG and Gaudemaris RD, Les lombalgies Etude des circonstances et conséquences socio-économiques des accidents du travail sur 2 ans. Arch Mal Prof 1992; 727-32.

22. Leger D, Voisin C and Conso F. Handicaps et incidences socio-économiques dans la pathologie lombaire commune. Edn Tech Appareil Locomoteur 1994; 815: 41-10.

23. Gaudemaris RD, Blatier JF, Quinton O, Piazza E, Gallin-Martel C, Perdrix A et al., Analyse du risque lombalgique en milieu professionnel. Rev Epidémiol Santé Publ 1986; 308-17.

24. Adams MA, Mannion AF and Dolan P. Personal risk factors for first-time low back pain. Spine 1999: 2497-505.

25. Smedley J,Trevelyan F, Inskip H, Buckle P, Cooper C and Coggon D. Impact of ergonomic intervention on back pain among nurses. Scand J Work Environ Health 2003; 117-23. 
26. Burgmeier AC, Blindauer B and Lehmann R. Incidence, prévalence et facteurs de risque de lombalgies hospitalières. Perspective de prévention. Med Trav 1987; 28-34.

27. Frank a and Townsend J. Low back pain. Smoking linked to back pain. Br Med J 1993; 1268.

28. Thomas E and Blotman F, Tabagisme et lombalgies. Rev Rhum Ed Fr 653 1998; 63-7.

29. Fanello S, Furber A, Cardinal SL, Furber A, Roquelaure Y and Penneau-Fontbonne D. La pathologie lombaire chez les médecins: Incidence, prévalence et facteurs de risque. Concours Méd 1994; 2937-40.

30. Demblans-Dechans B, Ayrolles C, Clement JL, Lassoued S, Fournie B and Fournie A, Biomécanique lombaire et sport: l'isthmolyse de L5. Rev Rhum 1988; 405-10.

31. Le Goff P and Bontoux D, Le sport parmi les facteurs de risque de la lombalgie. Rev Rhum (Ed Fr) 1998; 43-7.

32. Troussier B, Lamalle Y, Charruel C, Rachidi Y, Jiguet M, Vidal F et al., Incidences socio-économiques et facteurs pronostiques des lombalgies par accidents de travail chez le personnel hospitalier du. CHU de Grenoble. Rev Rhum (Ed Fr) 1993; 144-51.

33. Bordes G, Oliva M and Fortin P, Le mal au dos: enquête sur les douleurs du dos et le travail assis. Arch Mal Prof 1996; 64-6.

34. Massironi F, Mian P, Olivato D and Bacis M, Exposure to the risk of the manual lifting of patients and the results of a clinical study in 4 hospital establishments of northern Italy. Med Lav 1999; 330-41.

35. Yves Henchoz and Alexander Kai-Lik So. Exercise and nonspecific low back pain: A literature review Joint Bone Spine 2008; 75(5): 533-9.

36. Fanello S, Durand Stocco C, Jarny C, Chotard Frampas V and Roquelaure Y, Le mal de dos et les soignants : Vers de nouvelles modalités de prévention. Concours Méd 1999; 1934-8.

37. Alcalay M, Duplan B, Roche JF, Debiais F and Mallen G, Facteurs psychologiques et lombalgie. Rev Rhum (Ed Fr) 1998; 68-79.

38. Epping-Jordan JE, Wahlgren DR, Williams RA, Pruit SD, later MA, Potterson TL et al., Transition to chronic pain in men with low back pain: predictive relashionship among pain intensity, disability and depressive symptoms. Health Psychol 1998; 421-7.

39. Gonge H, Jensen LD and Bonde JP. Do psychosocial strain and physical exertion predict onset of low back pain among nursing aides. Scand J Work Environ Health 2001; 388-94.

40. Burton AK, Symonds TL, Zinzen E, et al. Is ergonomic intervention alone sufficient to limit musculoskeletal problems in nurses, Occup Med (Lond) 1997; 47: 25-32.

41. Gatchel RJ, Polatin PB, Noe C, et al. Treatment- and cost-effectiveness of early intervention for acute low-back pain patients: a one-year prospective study. J Occup Rehabil 2003;13: 1-9.

42. Larsen EC, Wilken-Jensen C and Hansen A et al., Symptom-giving pelvic girdle relaxation in pregnancy: I. Prevalence and risk factors, Acta Obstet Gynecol Scand 1999: 105-10.

43. Nwuga VCB , Pregnancy and back pain among upper class Nigerian women, Aust J Physiother 1982: 243-5. 